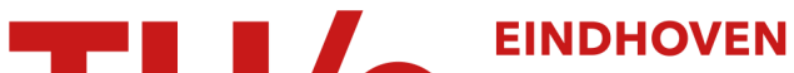 UNIVERSITY OF TECHNOLOGY
}

\section{Human neutrophil cytosolic phospholipase C: partial characterization}

Citation for published version (APA):

Faber, A. J., \& Aviram, I. (1992). Human neutrophil cytosolic phospholipase C: partial characterization. Biochimica et Biophysica Acta, Lipids and Lipid Metabolism, 1128(1), 8-13. https://doi.org/10.1016/00052760(92)90251-P

DOI:

10.1016/0005-2760(92)90251-P

Document status and date:

Published: 01/01/1992

\section{Document Version:}

Publisher's PDF, also known as Version of Record (includes final page, issue and volume numbers)

\section{Please check the document version of this publication:}

- A submitted manuscript is the version of the article upon submission and before peer-review. There can be important differences between the submitted version and the official published version of record. People interested in the research are advised to contact the author for the final version of the publication, or visit the $\mathrm{DOI}$ to the publisher's website.

- The final author version and the galley proof are versions of the publication after peer review.

- The final published version features the final layout of the paper including the volume, issue and page numbers.

Link to publication

\section{General rights}

Copyright and moral rights for the publications made accessible in the public portal are retained by the authors and/or other copyright owners and it is a condition of accessing publications that users recognise and abide by the legal requirements associated with these rights.

- Users may download and print one copy of any publication from the public portal for the purpose of private study or research.

- You may not further distribute the material or use it for any profit-making activity or commercial gain

- You may freely distribute the URL identifying the publication in the public portal.

If the publication is distributed under the terms of Article 25fa of the Dutch Copyright Act, indicated by the "Taverne" license above, please follow below link for the End User Agreement:

www.tue.nl/taverne

Take down policy

If you believe that this document breaches copyright please contact us at:

openaccess@tue.nl

providing details and we will investigate your claim. 
BBALIP 53997

\title{
Human neutrophil cytosolic phospholipase C: partial characterization
}

\author{
Anat Faber and Irit Aviram \\ Department of Biochemistry, Tel Aviv Unicersity. Tel Aliv (Israel) \\ (Received 4 February 1992) \\ (Revised manuscript received 9 June 1992)
}

Key words: Neutrophil; Cytosolic; Phospholipase C; Phosphoinositide

\begin{abstract}
The activity of neutrophil cytosolic phospholipase C on PIP ${ }_{2}$ and PI was compared employing [ $\left.{ }^{3} \mathrm{H}\right]$ inositol-labeled heat-inactivated membranes of differentiated HL-60 cells, into which tracer [ ${ }^{32}$ P]PIP 2 was incorporated. Hydrolysis of PIP $P_{2}$ did not require $\mathrm{Ca}^{2+}$ and was stimulated when the content of PIP $P_{2}$ in the inembrane was increased by incorporation of unlabeled inositol lipid. At equal concentrations of PI and PIP $P_{2}$ in the membrane, hydrolysis of PIP was faster and no evidence of competition between the two substrates was obtained. Incorporation of PI into PE-[ ${ }^{32}$ P]PIP 2 vesicles, accelerated PIP $P_{2}$ hydrolysis also at conditions that favor hydrolysis of PI. Partial purification of neutrophil cytosolic PLC on Q Sepharose, phenyl Sepharose and heparin-Agarose columns is described. From heparin-Agarose column, two PLC activity peaks exhibiting different substrate specificities were eluted. The elution profile of the main PLC species from Superose 12 gel filtration column was compatible with an approx. $150 \mathrm{kDa}$ protein.
\end{abstract}

\section{Introduction}

Phosphoinositide-specific phospholipase C (PLC) participates in signal transduction initiated by hormones, neurotransmitters and growth factors [1,2]. Following cell stimulation, PLC catalyzes hydrolysis of phosphatidylinositol 4,5-biphosphate (PIP,) to generate two second messengers, $s n-1,2$-diacylglycerol (DAG) and inositol 1, 4, 5-trisphosphate $\left(\mathrm{IP}_{3}\right)$ [3]. Activation of PLC may be mediated by receptor-coupled $\mathbf{G}$ proteins or by the tyrosine kinase activity of receptors to growth factors [4]. Mammalian PLC in their membrane-bound or cytosolic forms consist of at least four isozymes, designated $\alpha, \beta, \tau$ and $\delta$. The isozymes differ in their structure, molecular mass and activity.

Surface-receptors for chemotactic ligands expressed by neutrophils are coupled to PLC-mediated phosphoinositide hydrolysis. Due to this, neutrophils and the related leukemia HL-60 cell line cells, have been extensively used as models for studies of signal transduc-

\footnotetext{
Correspondence to: 1. Aviram. The Department of Biochemistry, Tel Aviv University, Tel Aviv 69978, Israel.

Avioreviations: PLC, phosphoinositide-specific phospholipase C; DAG, 2-diacylglycerol; PIP $_{2}$, phosphatidylinositol 4,5-bisphosphate: IP $_{3}$, inositol 1,4,5-trisphosphate; PE, phosphatidylethanolamine.
}

tion pathways involving inositol lipid turnover [5-8]. Participation of G proteins in the activation of PLC in intact and permeabilized neutrophils and in neutrophil membranes has been documented $[9,10]$. Only few studies, however, have been devoted to the characterization of neutrophil PLC at the molecular level [11,12]. In this present report, a partial characterization of cytosolic neutrophil PLC with respect to its activity and structure, is presented. Preliminary data of this study have been published [13].

\section{Materials and Methods}

Materials. Dowex-AG-X8 (100-200 mesh, formate form) was purchased from Bio-Rad. Culture media RPMI-1640 and M-199 were obtained from Biological Industries (Beth Haemek). All other materials were from Sigma.

Fractionation of neutrophils. Human neutrophils were isolated from fresh buffy coats by standard procedures of dextran sedimentation, Ficoll density gradient centrifugation and hemolysis. The cells were broken and fractionated as described elsewhere [14].

Synthesis of $I^{32} P / P I P_{2}$ by human red blood cell PIP kinase [15]. PIP $(0.6 \mathrm{mg} / \mathrm{ml})$ was suspended by bath sonication in $50 \mathrm{mM}$ Mes (pH 6.5) $2 \mathrm{mM}$. EGTA/2 mM EDTA. Red blood cell membranes were suspended at $1.5 \mathrm{mg}$ protein $/ \mathrm{ml}$ in $10 \mathrm{mM}$ Tris- $\mathrm{HCl}(\mathrm{pH}$ 
7.4) $1 \mathrm{mM}$ EGTA/250 mM sucrose/0.5\% CHAPS. 25 $\mu \mathrm{Ci}$ of $\left[\gamma-{ }^{32} \mathrm{P}\right] \mathrm{ATP}$ (Amersham, $3000 \mathrm{Ci} / \mathrm{mmol}$ ) were mixed with $100 \mu \mathrm{M}$ ATP solution in $100 \mu \mathrm{M} \mathrm{KP}{ }_{i}(\mathrm{pH}$ 7.5) $10 \mathrm{~m}^{*} \mathrm{vi} \mathrm{MnCl} / 20 \mathrm{mM} \mathrm{MgCl}{ }_{2}$ (final volume of 10 $\mu 1) .10 \mu$ l aliquots of PIP, ATP and red blood cell memb anes were mixed and incubated at $30^{\circ} \mathrm{C}$ for 3.5 h. The reaction was terminated by the addition of 30 $\mu$ ! of $5 \mathrm{mM} \mathrm{KP}$ and $2 \mathrm{ml}$ of chloroform $/$ methanol $/ \mathrm{HCl}$ $(800: 800: 4, v / v)$. After vortexing and incubation with shaking $\left(20 \mathrm{~min}\right.$ at $\left.37^{\circ} \mathrm{C}\right), 0.4 \mathrm{ml}$ of $0.6 \mathrm{M} \mathrm{HCl}$ was added and phases were separated by centrifugation. The lower phase was washed twice with $1 \mathrm{ml}$ chloroform/methanol/ $\mathrm{HCl}(3: 48: 47, \mathrm{v} / \mathrm{v})$ and its Cerenkov radiation was estimated. The radiolabeled lipid was stored at $-20^{\circ} \mathrm{C}$.

Preparation of $P E-I .32 P / P I P_{2}$ vesicles. Aliquots of [ ${ }^{32}$ P]PIP, (about $15000 \mathrm{cpm}$ ) were mixed with $1 \mu \mathrm{g}$ phospiatidylethanolamine (PE) and $2.5 \mu \mathrm{g}$ unlabeled $\mathrm{PIP}_{2}$ dissolved in chloroform. After evaporation of the solvent under a stream of nitrogen, the lipids were suspended by bath sonication $(20 \mathrm{~min})$ in the reaction buffer.

Preparation of heat-inactivated, $/{ }^{3} \mathrm{H} /$ inositol- and I $^{32} \mathrm{P} / \mathrm{PIP} \mathrm{P}_{2}$-labeled membranes. HL-60 cells were labeled with $\left[{ }^{3} \mathrm{H}\right]-$ myo-inositol (Amersham, 0.75-0.9 $\mu \mathrm{Ci} / \mathrm{ml}$ ) and isolated as described [16]. The membranes were heated for $10 \mathrm{~min}$ at $100^{\circ} \mathrm{C}$ to inactivate intrinsic membrane-bound PLC. For an assay, membranes (about 15 $\mu \mathrm{g}$ of protein) were added to a test tube containing $10000 \mathrm{cpm}$ of dried $\left[{ }^{32} \mathrm{P}\right] \mathrm{PIP}{ }_{2}$ and the components were sonicated in a bath sonicator $(10 \mathrm{~min})$ to permit incorporation of $\left.\mathrm{PIP}_{2}: \because 7\right]$. For the preparation of $\mathrm{PIP}_{2}$-enriched membranes, unlabeled $\mathrm{PIP}_{2}$ was premixed with $\left[{ }^{32} \mathrm{P}\right] \mathrm{PIP}{ }_{2}$ to give a final $1: 1$ molar ratio of PI: PIP ${ }_{2}$.

Enzyme activity of cytosolic PLC. Neutrophil cytosol (about $240 \mu \mathrm{g}$ protein $/ \mathrm{ml}$ ) was incubated with one of the labeled substrates $\left(6 \mathrm{~min}, 37^{\circ} \mathrm{C}\right.$ ) in $0.05 \mathrm{ml}$ (for PE-PIP ${ }_{2}$ vesicles) or $0.25 \mathrm{ml}$ (for labeled membranes) reaction mixtures containing $50 \mathrm{mM}$ Hepes (pH 6.7) 5 $\mathrm{mM} \mathrm{MgCl} / 10 \mathrm{mM} \mathrm{LiCl} / 3 \mathrm{mM}$ EGTA. $\mathrm{CaCl}_{2}$ was added to the desired concentration calculated according to Schatzman [18]. Activities of column fractions were determined at $2.3 \mu \mathrm{M}$ free $\mathrm{Ca}^{++}$plus $340 \mu \mathrm{M}$ arachidonate [16]. Hydrolysis was terminated by the addition of chloroform/methanol $(2: 1, \mathrm{v} / \mathrm{v})$. Inositol phosphates were isolated on Dowex AG1-X8-formate columns eluted with $0.2 \mathrm{M}$ ammonium formate $/ 1.0 \mathrm{M}$ formic acid and their radioactivities were determined in liquid scintillation counter [19].

Gel filtration of cytosolic PLC on Superose-12. Cytosol (1 mg in $0.25 \mathrm{ml}$ ) was fractionated on a Superose12 column equilibrated with $10 \mathrm{mM} \mathrm{KP} \mathrm{P}_{\mathrm{i}}(\mathrm{pH} 7.0) 131$ $\mathrm{mM} \mathrm{NaCl} / 0.5 \mathrm{mM}$ EGTA/0.5 $\mu \mathrm{M}$ PMSF $/ 1 \mu \mathrm{g} / \mathrm{ml}$ leupeptin employing an HPLC-system of Waters, Milford, MA. Fractions of $0.3 \mathrm{ml}$ were collected (flow rate was $0.2 \mathrm{ml} / \mathrm{min})$ and their enzymic activities were determined.

Chromatography of cytosolic PLC on a $Q$ Sepharose column. Cytosol (ca. $12 \mathrm{mg}$ protein) was diluted with 2 vol of $10 \mathrm{mM}$ Hepes $(\mathrm{pH} 7.5)$ and loaded at a flow rate of $12 \mathrm{ml} / \mathrm{h}$ onto a $Q$ Sepharose column $(1.5 \mathrm{ml})$, equilibrated with $10 \mathrm{mM}$ Hepes (pH 7.5) $43 \mathrm{mM} \mathrm{NaCl}$. The column was washed and the proteins were eluted with a linear gradient of $0.043-0.6 \mathrm{M} \mathrm{NaCl}(20 \mathrm{ml})$. Fractions of $1 \mathrm{ml}$ were collected and stored at $-20^{\circ} \mathrm{C}$ up to 6 months without luss of activity.

Chromatography of PLC on a phenyl-Sepharose column. Active fractions from $Q$ Sepharose were concentrated by ultrafiltration (Diaflo membrane XM-100, Amicon, MA), mixed with $0.8 \mathrm{M}$ ammonium sulfate aut applied $(12 \mathrm{ml} / \mathrm{h})$ to a phenyl-Sepharose column $(2 \mathrm{ml})$ equilibrated with $0.8 \mathrm{M}$ ammonium sulfate/10 $m M \mathrm{KP}_{\mathrm{i}}(\mathrm{pH}$ 6.7). The column was washed and proteins were eluted with $8 \mathrm{ml}$ of $\mathrm{KP}_{\mathrm{i}}$-buffered $0.3 \mathrm{M}$ ammonium sulfate followed by $8 \mathrm{ml}$ of $40 \%(\mathrm{v} / \mathrm{v})$ $\mathrm{KP}_{\mathrm{i}}$-buffered ethylene glycol. Fractions of $1 \mathrm{ml}$ were collecied and stored at $-20^{\circ} \mathrm{C}$.

Separation of cytosolic PLC forms by heparin-Agarose. Cytosol $(0.4 \mathrm{ml}, 1.65 \mathrm{mg}$ protein) was diluted with an equal volume of $10 \mathrm{mM}$ Hepes $(\mathrm{pH} \mathrm{7.5)}$ and applied $(10 \mathrm{ml} / \mathrm{h})$ to a column preequilibrated with $10 \mathrm{mM}$ Hepes (pH 7.5) $65 \mathrm{mM} \mathrm{NaCl}$. After washing, proteins were eluted stepwise with $0.2 \mathrm{M}, 0.5 \mathrm{M}$ and $0.8 \mathrm{M}$ Hepes-buffered $\mathrm{NaCl}$ solutions. $1 \mathrm{ml}$ fractions were collected.

Protein determination. The method of Bradford was employed, with bovine serum albumin as a standard [20].

\section{Results}

In the first part of this study, neutrophil cytosol was employed as a source of PLC to follow hydrolysis of $\mathrm{PIP}_{2}$ in PE-[ ${ }^{32} \mathrm{P}_{\mathrm{PIP}}$ vesicles. Formation of the products proceeded linearly with time (up to $6 \mathrm{~min}$ ) and with the concentration of cytosolic proteins. At concentrations exceeding about $240 \mu \mathrm{g}$ protein $/ \mathrm{ml}$ deviations from linearity were observed (data not shown).

$\mathrm{PIP}_{2}$ hydrolysis did not require $\mathrm{Ca}^{2+}$ and proceeded also in the presence of $3 \mathrm{mM}$ EGTA (Table $\mathrm{I}$ ); rates of substrate breakdown were augmented by arachidonate and $\mathrm{Ca}^{2+}$. Arachidonate and other $c$ is-unsaturated fatty acids, in the presence of $\mathrm{Ca}^{2+}$, were previously shown to dramatically stimulate PI hydrolysis by neutrophil cytosolic PLC [16].

Incorporation of $\mathrm{PI}$ into the $\mathrm{PE}\left[{ }^{32}-\mathrm{P}^{3}\right] \mathrm{PIP} \mathrm{P}_{2}$ vesicles at a 1:1 molar ratio to PIP $_{2}$ was expected to inhibit PIP $_{2}$ hydrolysis by competition between the two substrates for the available enzyme [21]. Pl, however, markedly augmented rates of PIP ${ }_{2}$ breakdown, also at conditions previously shown by us to stimulate PI breakdown, i.c., 


\section{TABLE I}

The effect of PI on the hydrolysis of $I^{32} \mathrm{PIPIP}_{2}$ in PE.PIP 2 lesicles a a PE-PIP, vesicles contained $1 \mu \mathrm{g}$ PE, $2.5 \mu \mathrm{g}$ unlabeled PIP $\mathrm{P}_{2}$ and [ ${ }^{32} \mathrm{P}$ ].PIP 2 (15000 cpm). When indicated, $2.5 \mu \mathrm{g} \mathrm{PI}$ was also incorporated into the vesicles.

\begin{tabular}{llc}
\hline Additions & {$\left[{ }^{32} \mathrm{P}\right] \mathrm{PIP}$} & hydrolyzed $(\mathrm{nmol} / \mathrm{min}$ per $\mathrm{mg})$ \\
\cline { 2 - 3 } & PE-PIP 2 vesicles & PE-PIP ${ }_{2}$-PI vesicles \\
\hline None & 1.29 & 4.16 \\
$\mathrm{Ca}^{2+}(2.3 \mu \mathrm{M})$ & 2.26 & 16.30 \\
Arachidonate $(340 \mu \mathrm{M})$ & 1.58 & 5.56 \\
$\mathrm{Ca}^{2+}$ plus arachidonate & 6.41 & 22.24 \\
\hline
\end{tabular}

in the presence of $\mathrm{Ca}^{++}$and arachidonate [16] (Table I).

The opposite situation, namely the effect of PIP, on the hydrolysis of PI, was investigated in heat-inactivated membranes which may be considered closer to the natural milieu of cellular phospholipids than PE-PIP ${ }_{2}$ vesicles (see Discussion). Since labeling of $\mathrm{PIP}_{2}$ in [ $\left.{ }^{3} \mathrm{H}\right]$ inositol membranes is very low [16], tracer $\left[{ }^{32} \mathrm{P}\right] \mathrm{PIP} \mathrm{P}_{2}$ was incorporated into $\left[{ }^{3} \mathrm{H}\right]$ inositol membranes to tag endogenous PIP ${ }_{2}$ [17]. In some of the experiments, [ $\left.{ }^{32} \mathrm{P}\right] \mathrm{PIP} \mathrm{P}_{2}$ was supplemented with unla-

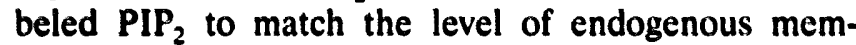
brane PI ( PIP $_{2}$-enriched membranes). Table II summarizes activities of cytosolic PLC on the two substrates in both types of membrane. In regular membranes, with PI as the predominant inositol lipid, in the absence of $\mathrm{Ca}^{2+}$ and arachidonate as well as in the presence of either one, rates of hydrolysis of both substrates by cytosolic PLC were low. Simultaneous presence of $\mathrm{Ca}^{2+}$ and arachidonate enhanced hydrolysis of both PI and PIP $_{2}$, the effect on PI being much more pronounced. Enrichment of the membrane by PIP, to a PI:PIP, molar ratio of $1: 1$, substantially increased rates of PIP,

\section{TABLE II}

Pl.C.catulyzed hydrolusis of $I \cdot H \mid P I$ and l'PPIPIP: effect of PI:PIP ratio

"Tracer-["2 P]PIP, was incorporated into ['H]PJ-laheled inactivated neutrophil membranes without affecting the $\mathbf{P I}: \mathbf{P I P}_{2}$ ratio, "['P]PIP, plus unlabeled PIP, were incorporated into [ ['H]P]labeled inactivated neutrophil membranes resulting in a $\mathbf{P I}: \mathbf{P I P}$, ratio of $1: 1$. The concentrations of $\mathrm{Ca}^{2+}$ and arachidonate were $2.3 \mu \mathrm{M}$ and $340 \mu \mathrm{M}$. respectively.

\begin{tabular}{|c|c|c|c|c|c|}
\hline \multicolumn{2}{|c|}{ Additions " } & \multicolumn{4}{|c|}{ Activity (pmol/min per mg protein) } \\
\hline \multirow[t]{3}{*}{$\overline{\mathrm{Ca}^{++}}$} & \multirow[t]{3}{*}{ arachid. } & \multicolumn{2}{|c|}{ Membrane " } & \multirow{2}{*}{\multicolumn{2}{|c|}{$\begin{array}{l}\text { Enriched } \\
\text { membrane b }\end{array}$}} \\
\hline & & \multirow[t]{2}{*}{$\overline{\mathbf{P I}}$} & \multirow[t]{2}{*}{$\overline{\mathbf{P I P}_{2}}$} & & \\
\hline & & & & $\overline{\mathbf{P I}}$ & $\overline{\text { PIP }_{2}}$ \\
\hline$\overline{-}$ & - & $\leq 2$ & $\leq 2$ & $\leq 2$ & 49.7 \\
\hline- & + & $\leq 2$ & $\leq 2$ & $\leq 2$ & 41.4 \\
\hline+ & - & $\leq 2$ & $\leq 2$ & $\leq 2$ & 41.4 \\
\hline+ & + & 165.1 & 15.0 & 158.5 & 280.0 \\
\hline
\end{tabular}

TABLE III

Effects of guanine mucleotides and Nat on cytosolic PLC activity

\begin{tabular}{llr}
\hline Additions & \multicolumn{2}{l}{ Activity (cpm) } \\
\cline { 2 - 3 } & PI & PIP $_{2}$ \\
\hline None & n.d. & 2170 \\
GTP $\gamma S$ & n.d. & 2170 \\
GDP $\beta S$ & n.d. & 543 \\
NaF & n.d. & 651 \\
\hline
\end{tabular}

activity was determined using double-labeled membranes [ $\left.{ }^{3} \mathrm{H}\right] \mathrm{in}$ ositol-5000 cpm/assay; [ ${ }^{32}$ P]PIP $2-10000 \mathrm{cpm} /$ assay); $2.3 \mu \mathrm{M} \mathrm{Ca}^{2+}$ and $80 \mu \mathrm{g}$ cytosolic protein. A representative experiment carried out in duplicate and repeated five times with essentially similar results.

bot detected.

hydrolysis even in the absence of activators, indicating that in regular membranes, PIP -PLC operated below $V_{\text {max }}$. Hydrolysis could be further stimulated by the addition of $\mathrm{Ca}^{2+}$ and arachidonate. Breakdown of $\mathrm{PI}$ in membranes and its stimulation by $\mathrm{Ca}^{2+}$ and arachi-
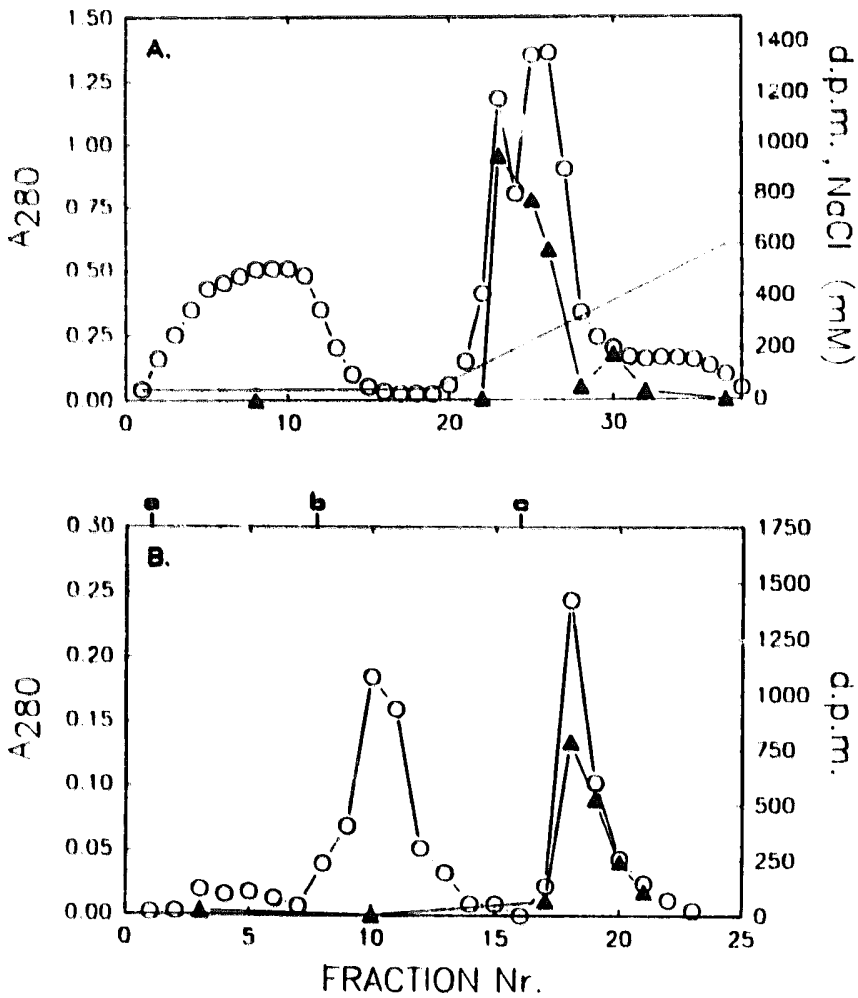

Fig. I. (A) Chromatography of cytosolic PLC on a Q Sepharose column. Neutrophil cytosol $(4 \mathrm{mg} / \mathrm{ml}, 3 \mathrm{ml})$ was applied to a $Q$ Sepharose column (1.5 ml), equilibrated with $10 \mathrm{mM}$ Hepes (pH 7.5) $43 \mathrm{mM} \mathrm{NaCl}$ and eluted with a linear gradient of $\mathrm{NaCl}$ (O) $\mathrm{A}_{280}$ ( $\triangle$ ) PI hydrolysis. In three similar experiments, the mean recovery of enzymatic activity equalled $110 \%$. (B) Chromatography of PLC on a phenyl-Sepharose column. Active pooled fractions from $Q$ Sepharose column were applied to a pheriyl-Sepharose column $(2 \mathrm{ml})$ equilibrated with $0.8 \mathrm{M}$ ammonium sulfate $/ 10 \mathrm{mM} \mathrm{KP_{i }}(\mathrm{pH} \mathrm{6.7)} \mathrm{(a).}$ Elution with (b) $0.3 \mathrm{M}$ ammonium sulfate (c) $40 \%$ ethylene glycol. $82 \%$ of the loaded activity was recovered. 


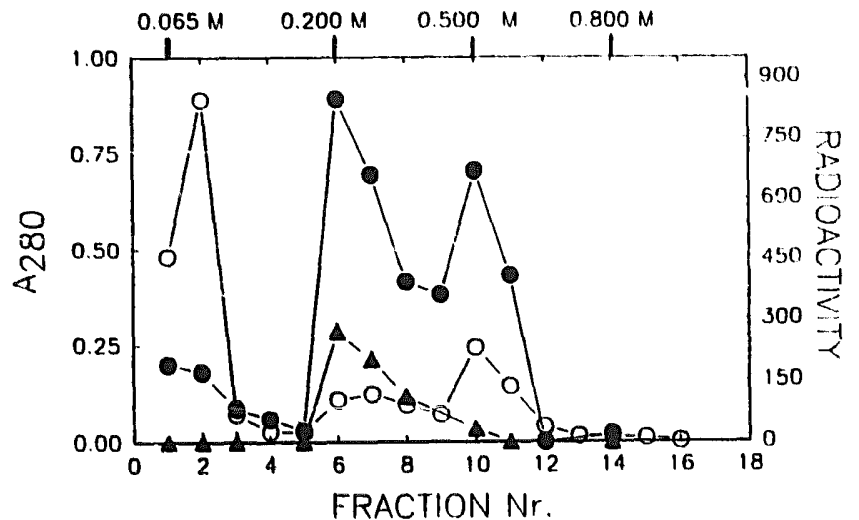

Fig. 2. Separation of cytosolic PLC on heparin-Agarose column. The column was preequilibrated with $10 \mathrm{mM}$ Hepes $/ 65 \mathrm{mM} \mathrm{NaCl}$. The sample loaded on the column contained $1.65 \mathrm{mg}$ cytosolic proteins. The $\mathrm{NaCl}$ content of the eluting solutions is indicated. Hydrolysis of

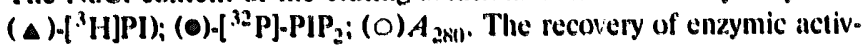
ity was $90 \%$ with respect to hoth substrates.

donate were not reduced by enrichment with PIP $_{2}$ in spite of simultaneous hydrolysis of the latter. Thus, no inhibition of PI hydrolysis by the competing substrate, PIP $_{2}$, was observed.

GTP $y \mathrm{~S}(\mathrm{i}-\mathrm{i} 00 \mu \mathrm{M})$ was unable to enhance activity of cytosolic PLC when tested in either PE-PIP ${ }_{2}$ vesicles or in the double labeled membranes (Table III). This result was obtained at different concentrations of calcium ions. GDP $\beta S(400 \mu \mathrm{M})$ inhibited hydrolysis of $\mathrm{PIP}_{2}$ in both forms of substrate presentation and unexpectedly $\mathrm{NaF}(10 \mathrm{mM})$ also reduced activity in both cases (Table III).

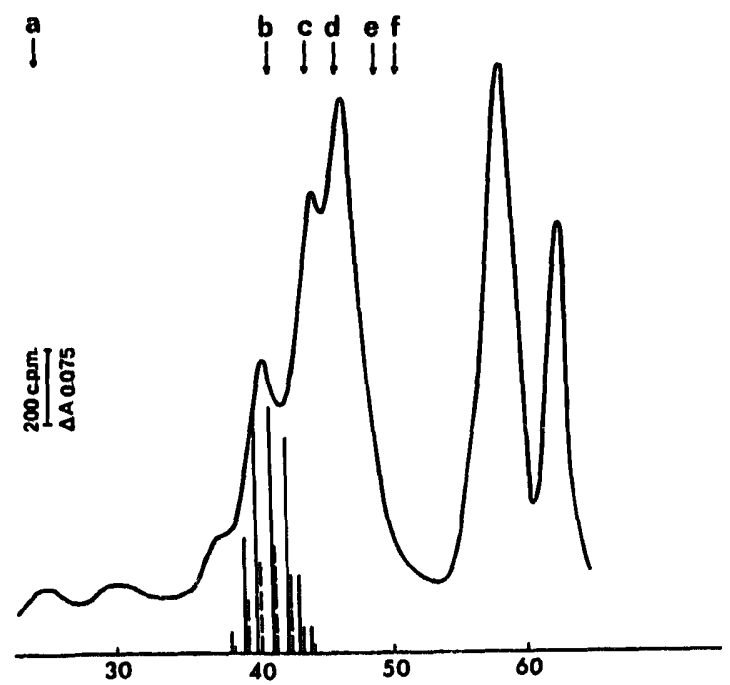

Fig. 3. HPLC analysis of cytosolic PLC on a Superose-12 column. $0.25 \mathrm{ml}$ cytosol was loaded on the column as described in the experimental section. For activity determination $\left[{ }^{32} \mathrm{P}_{\mathrm{PIP}}\left(-\mathrm{P}_{2}(-)\right.\right.$ and $\left[{ }^{3} \mathrm{H}\right]$ inositol $(--\infty)$ labeled heat-inactivated membranes were employed. Molecular mass standards (kDa): a, 669; b, 150; c, 67; d, $45 ; \mathrm{e}, 24 ; \mathrm{f}, 12.5$.
Physicochemical properties of cytosolic PLC

The main PI-hydrolyzing activity peak of cytosoiic PLC eluted from Q Sepharose anion-exchange column at $0.15 \mathrm{M} \mathrm{NaCl}$ concentration (Fig. 1A). On phenyl Sepharose, the single activity peak was eluted at $40 \%$ ethylene glycol (Fig. 1B). On both columns, PIP $_{2}$ and PI-hydrolyzing activities coeluted (data not shown).

When cytosol was fractionated on a heparin-Agarose column (Fig. 2), two activity peaks were detected: the enzyme present in the first peak, eluting at $0.2 \mathrm{M}$ salt, acted on both substrates, $\mathrm{PIP}_{2}$ and PI. The second activity peak, eluted with $0.5 \mathrm{M} \mathrm{NaCl}$, exhibited mainly $\mathrm{PIP}_{2}$-hydrolyzing activity. This finding suggested the presence of at least two different isozymes in the cytosol.

The molecular mass of the main peak of cytosolic PLC was estimated on Superose 12-HPLC clumn (Fig. 3). The enzyme coeluted with alcohol dehydrogenase (molecular mass $150 \mathrm{kDa}$ ). A similar molecular mass was detected in sucrose gradients (data not shown).

\section{Discussion}

Most studies on inositol lipid-specific PLC in neutrophils dealt with membrane-associated enzyme in intact, permeabilized or broken cell preparations [5-9]. The neutrophil enzyme was stimulated by binding of chemotactic ligands to surface receptors coupled to $G$ proteins [7-10].

In a previous communication, we described a remarkable enhancement of the activity of neutrophil cytosolic PLC by unsaturated fatty acids and calcium ions [16]. Stimulating effects of anionic phospholipids and amphiphiles and their ability to relieve PI hydrolysis from inhibition by long-chain phosphatidylcholine molecules, were demonstrated in other systems by Irvine et al. [22] and Hofmann and Majerus [23]. These authors attributed alterations in the activity of PLC caused by incorporation of certain lipids into the membrane, to the effects of the lipids on the physical structure of the substrate.

In the present report, we extended our earlier studies on PI-hydrolyzing activity of neutrophil cytosolic PLC [16] to hydrolysis of PIP $_{2}$ in membranes and PE-PIP 2 vesicles. The activity of cytosolic PLC on PIP $_{2}$ in PE-PIP 2 vesicles was also augmented by arachidonate and calcium; unlike PI breakdown, however, PIP hydrolysis proceeded also in the absc nce of both activating agents (Table I). The remarkable potentiation of $\mathrm{PIP}_{2}$-hydrolyzing activity by incorporation of $\mathrm{PI}$ in the absence of activators, namely at conditions unfavorable for PI hydrolysis, may be attributed to alterations in the physicochemical structure of the vesicles $[22-24]$. Alternatively, it can be suggested that PI as well as arachidonate interact with a resting or turning-over PLC at a site distinct from the active site of the 
enzyme. In a single case, binding of PLC to PI vesicles was indeed described [25].

In cellular signalling processes, PIP $_{\mathbf{2}}$ is hydrolyzed preferentially to $\mathrm{PI}$, to give two second messengers, $\mathbf{I P}_{\mathbf{3}}$ and diacyl glycerol $[1,2]$. Potentiation of PIP $_{2}$ hydrolysis by PI demonstrated in the present study (Table I), may constitute a factor that contributes to the preferential cleavage of PIP $_{2}$ in biological membranes. It should be pointed out, however, that our data were obtained employing lipid vesicles and not membranes as a substrate.

Experiments conducted with membranes (Table II) permitted direct comparison of activities of neutrophil cytosolic PLC on PI and PEP $_{2}$ in a milieu which may be considered as close as possible to the natural milieu in the cell. Although the heat pretreatment of the membranes, employed by us to inactivate intrinsic PLC, might have introduced alterations in their topography, the overall composition of the membrane was retained. Since in vivo the negatively charged inositol lipids and particularly PIP $_{2}$ are bound to membrane proteins [26], the presence of proteins in the microenvironment of the substrate may represent an advantage over pure lipid or lipid-detergent vesicles.

In HL-60 cell membranes in which the ratio of PI: PIP 2 is approx. 93.8:2.3 [27], hydrolysis of both inositol substrates by cytosolic PLC proceeded at low and similar rates (Table II). The presence of arachidonate and calcium rendered PI the preferable substrate, although cleavage of PIP $_{2}$ was also enhanced. Hydrolysis of PIP, was stimulated by the enrichment of the membranes with exogenous PIP ${ }_{2}$. Assuming that the presentation of membrane-incorporated PIP $P_{2}$ and intrinsic PIP, to the enzyme are similar [17], these data imply that prior to the enrichment, the rate of PIP $_{2}$ breakdown was below $V_{\max }$. The experiments summarized in Table $I I$ indicate also that at equal $\mathrm{PI}$ and PIP concentrations, neutrophil cytosolic PLC acts preferentially on PIP ${ }_{2}$, in the presence as well as in the absence of $\mathrm{Ca}^{++}$. In spite of this preferential hydrolysis of PIP $_{2}$, excess of PIP incorporated into the membrane did not competitively inhibit the cleavage of PI stimulated by $\mathrm{Ca}^{2+} /$ arachidonate (Table II). This result may be attributed to dual and opposing effects of PIP acting both as a competing substrate that inhibits PI hydrolysis [21] and as a positive modulator which augments its breakdown. In membranes in which the effect of PIP on PI hydrolysis was tested (Table II) these opposing effects were of similar magnitude; in the reciprocal situation represented by PE-PIP, vesicles enriched by PI (Table I), the positive modulation by PI was stronger resulting in a net stimulation of PIP $_{2}$ hydrolysis. An alternative explanation for the lack of mutual inhibition of PIP $P_{2}$ cleavage by PI (Table I) or PI cleavage by $\mathrm{PIP}_{2}$ (Table II) may implicate PLC isozymes that differ in their kinetic parameters (affinity, $V_{\max }$ ) with respect to the two substrates. This possibility is indeed implied by chromatography on heparin-Agarose which revealed only one activity peak exhibiting substantial activity on PI (Fig. 2).

The elution profile of PLC activity from a heparinAgarose column is consistent with the presence of at least two isozymes (Fig. 2). Miost living cells contain several isozymes of PLC which differ in their structure and activity $[1,2,4]$. Three species of PLC were previously detected by gel filtration of neutrophil cytosol [28]. The size of one of them resembled the main PLC species of neutrophil PLC reported in this study (Fig. 4) and was compatible with the size of $\beta$ or $\gamma$ isozymes of PLC. PLC $\gamma_{1}$ which undergoes phosphorylation on tyrosyl residues by the growth factor-stimulated kinase activity of the receptor has been detected in most living cells [4]. Moreover, in the promyelocytic leukemia HL60 cells, which upon appropriate induction undergo maturation into cells that resemble neutrophils, PLC $\gamma$ and PLC $\beta$ forms have been identified [4,27].

The deviations from linearity of PLC activity observed by us at high concentrations of cytosol, cannot be attributed to exhaustion of the substrate (less then $15 \%$ was hydrolysed) nor to accumulation of products of the reaction. They may reflect the presence in the cytosol of an endogenous inhibitor loosely associated with the enzyme and its dissociation upon dilution of cytosol.

Stimulation of inositol lipid hydrolysis by guanine nucleotides compatible with involvement of $\mathbf{G}$ proteins in the activity of neutrophil PLC has been described by many investigators [8-10, 29-32]. In our hands, the activity of neutrophil cytosolic PLC assayed in lipid vesicles or in heat-inactivated membranes devoid of active $G$ proteins 'vas not affected by GTP $\gamma S$ (Table III). Moreover, fluoride and GDPBS exerted an unexplained inhibition of the enzymic activity (Table III). In parallel experiments carried out on membrane PLC acting on endogenous substrate, we observed stimulation of the enzyme by GTP $\gamma$ S (data not shown). These results may imply that either PLC isozymes present in neutrophil cytosol are not regulated by $G$ proteins (e.g., PLC $\gamma$ ) or/and that compatible G proteins were not present in the cytosolic preparations. In the closely related permeabilized HL-60 cells, Cockroft et al. indeed described restoration of GTP $y$ S-elicited responses by rat brain soluble phospholipases $C$ of $\beta$ and $\epsilon$ types, but not by the PLC $\gamma$ [26], indicating that G proteins responsible for the stimulation were present in membranes of the permeabilized cells. Contrary to this, Camps et al. [33] have recently demonstrated activation of cytosolic PLC from differentiated HL-60 cells by $\mathrm{GTP}_{\gamma} \mathrm{S}$, implicating soluble $\mathrm{G}$ protein $/ \mathrm{s}$ in activation of the enzyme. Further characterization and resolution of neutrophil cytosolic PLC forms will be required to clarify the mode of their regulation. 


\section{References}

1 Rhee, S.G., Suh, P.-G., Ryu, S.-H. and Lee, S.Y. (1989) Science 244, 546-550.

2 Majerus, P.W., Ross, T.S., Cunningham, T.W., Caldwell, K.K., Jefferson, A.B. and Bansal, V.S. (1990) Cell 63, 459-465.

3 Berridge, M.J. (1984) Biochem. J. 220, 345-360.

4 Rhee, S.G., Kim, H., Suh, P.G. and Choi, W.C. (1991) Biochem. Soc. Trans. 19, 337-341.

5 Cockcroft, S., Bennett, J.P. and Gomperts, B.D. (1981) Biochem. J. 200, 501-508.

6 Volpi, M., Yassin, R., Naccache, P.H. and Sha'afi, R.J. (1983) Biochem. Biophys. Res. Commun. 112, 957-964.

7 Bradford, P.G. and Rubin, R.P. (1985) Biochem. J. 329, 97-102.

8 Verhese, M.W., Smith, C.D. and Snyderman, R. (1986) J. Cell. Binchem. 32, 59-69.

9 Cockcroft, S. (1986) Biochem. J. 240, 503-507.

10 Ohta, H., Okajima, F. and Ui, M. (1985) J. Biol. Chem. 260, 15771-5780.

11 Mackin, W.M. and Stevens, T.M. (1988) J. Leuk. Biol. 44, 8-16.

12 Mackin, W.M. (1989) Agents Actions 27, 3-4.

13 Faber, A. and Aviram, I. (1991) Eur. J. Clin. Invest. 21, 41 A.

14 Aviram, I. and Sharabani, M. (1989) Biochem. J. 261, 477-482.

15 Sharoni, Y., Teuerstein, I. and Levy, J. (1986) Biochem. Biophys. Res. Conımun. 134, 876-883.

16 Faber, A. and Aviram, I. (1991) Biochem. Int. 23, 751-758.

17 Litosch, I. (1989) Biochem. J. 261, 325-331.

i8 Schatzmann, J.H. (1973), J. Physiol. 235, 551-
19 Berridge, M.J., Dawson, R.M.C., Downes, C.P., Heslop, J.P. and Irvine, R.F. (1983) Biochem. J. 212, 473-482.

20 Bradford, M. (1976) Anal. Biochem. 72, 248-254.

21 Wilson, D.B., Bross, T.E., Hofmann, S.L. and Majerus, P.W. (1984) J. Biol. Chem. 259, 11718-11724.

22 Irvine, R.F., Letcher, A.J. and Dawson, R.M.C. (1979) Biochem. J. 178, 497-500.

23 Hofmann, S.L. and Majerus, P.W. (1982) J. Biol. Chem. 257, 14359-143654.

24 Jackowski, S. and Rock, C.O. (1989) Arch. Biochem. Biophys. 268, 5116-524.

25 Herrero, C., Cornet, M.E., Lopez, C., Barreno, P.G. and Municio, A.M. (1988) Biochem. J. 255, 807-812.

26 Brophy, P.J., Burbach, P., Nelemans, J., Westerman, J., Wirtz, K.W.A. and Van Deenen, L.L.M. (1978) Biochem. J. 174, 413420.

27 Thomas, G.M.H., Geny, B., and Cockcroft, S. (1991) EMBO J. 10, 2507-2512.

28 Balsinde, J., Diez, E., Fernandez, B. and Mollinedo, F., (1989) Eur. J. Biocheni. 186, 717-724.

29 Brandt, S.J., Dougherty, R.W.. Lapetina, E.G. and Niedel, J.E. (1985) Proc. Natl. Acad. Sci. USA 82, 3227-3280.

30 Anthes, J.C., Billah, M.M., Cali, A., Egan, R.W. and Siegel, M.I. (1987) Biochem. Biophys. Res. Commun. 145, 825-833.

31 Cockroft, S. and Gomperts, B.D. (1985) Natı 314, 534-536.

32 Dillon, S.B., Murray, J.J., Uhing, R.J. and Snyderman, R. (1987) J. Cell. Biochem. 35, 345-359.

33 Camps, M., Hou, C., Jacobs, K.H. and Gierschik, P. (1990) Biochem. J. 271, 743-748. 